\title{
The impact of employees' commitment on organizational performances
}

\author{
Biljana Đorđević \\ Faculty of Economics, University of Niš, Niš, Serbia \\ Maja Ivanović-Đukić \\ Faculty of Economics, University of Niš, Niš, Serbia \\ Vinko Lepojević \\ Faculty of Economics, University of Niš, Niš, Serbia \\ Sandra Milanović \\ Innovation Center, University of Niš, Niš, Serbia
}

\begin{abstract}
This paper examines the impact of employees' commitment on the productivity of organizations in the Republic of Serbia. Employees' commitment represents the willingness of employees to make efforts for the benefit of the organization and the desire to remain in them. It can be seen as: affective, continuous and normative commitment. Affective commitment reflects a belief in the goals of an organization and a willingness to actively participate in its development; normative commitment reflects a sense of obligation on employees to remain in the organization while continuing commitment is due to employees' assessment that leaving the organization causes greater costs than benefits. Previous research shows that all types of commitment have a major impact on the performance of organizations. As the number of empirical studies on this topic in Serbia is limited, this paper examines the impact of each type of organizational commitment on the productivity of organizations in Serbia, as well as the impact of the overall commitment. The aim of the paper was to identify the types of organizational commitment that have the greatest impact on the performance of organizations in Serbia and to propose measures to HR managers whose implementation can improve the operations of domestic organizations. The starting point of the paper was that employees' commitment has a statistically significant effect on organizational performance. To verify the validity of this assumption, a primary survey was conducted. 169 employees of 17 organizations in Serbia were surveyed. By applying correlation and regression analysis methods, it has been proven that overall organizational commitment, as well as its certain types, have a positive impact on the productivity of organizations in Serbia, with the impact of normative commitment on performance greater than other types of commitment. At the same time, the contribution of continuous commitment to the performance of organizations in Serbia is negligible (statistically insignificant). In line with the obtained results, recommendations for human resources managers in Serbia are proposed. The theoretical implications of the paper are reflected in filling the gap in the national literature in the field of organizational commitment, while the empirical implications are reflected in the mechanisms and measures that are proposed at the end of the paper.
\end{abstract}

\section{Keywords}

employees' commitment, management, organizational performance, Serbia.

\section{Introduction}

Employees' commitment is a phenomenon that has been occupying the attention of the scientific and professional public for several decades. The reasons for this can be found in the fact that this phenomenon has a strong impact on many significant phenomena and outcomes in the working environment, such as absenteeism, turnover, employee performance etc. (Irefin \& Mechanic, 2014; Zia ud \& Khan, 2010; Folorunso, Adewale, \& Abodunde, 2014). Besides, some 
authors suggest that the competitive advantage of the organizations and their superior performance may be based precisely on the commitment of the employees that make up those organizations (Akintayo, 2010). In short, employees' commitment to the organizations has potentially serious consequences on the overall organizational performance (Irefin \& Mechanic, 2014).

Employees' commitment, however, is not an unambiguous phenomenon. The significant body of literature in this area suggests that this is a complex category that can be viewed from different angles. Accordingly, we can talk about the employees' commitment to an organization, commitment to work, commitment to oneself, commitment to colleagues, commitment to customers, etc. In this paper, the authors will analyse employees' commitment to an organization for which we will use the term organizational commitment as a synonym.

Organizational commitment is a complex category that can be observed through three types of commitment: affective, continuous and normative commitments (Meyer \& Allen, 1997). These types of commitment at the same time reflect the different reasons on which the commitment of employees to the organization is based on. Thus, some employees are committed to the organization because they strongly believe in the organizational values it stands for, the others are committed because of the high cost of leaving the organization, while some employees have a sense of moral obligation to the organization in which they are employed (Meyer \& Allen, 1997).

Having in mind the importance of the organizational commitment for many phenomena in the working place, but, above all, for the performance the employees achieve, and thus for the organizational performance, the subject of this paper is to examine the impact of organizational commitment, both overall and its different types, on the performance that companies in Serbia achieve. This paper's aims are to identify the types of organizational commitment that have the greatest impact on the performance of organizations in the Republic of Serbia and to propose measures for human resource managers whose implementation can improve the business of domestic companies.

The paper is structured as follows: first, the literature on the concept of organizational commitment is reviewed and the initial hypotheses are defined. Then, the research results and their discussion are presented while, at the end of the paper, concluding remarks and implications for managers are given.

\section{Literature review and hypothesis development}

\subsection{Organizational commitment}

Organizational commitment as a concept has been the subject of research for a long period. There are opinions that this concept, in addition to the concept of job satisfaction, is one of the most studied in management. The reason for that lies in the fact that it has been found that this phenomenon affects many outcomes and phenomena in the working place that directly or indirectly affect the overall results that organizations achieve, as well as the phenomena such as absenteeism, fluctuation and the like. Consequently, organizational commitment is recognized as an important component of the overall organizational success (Randall, Fedor \& Longenecker, 1990).

When it comes to the conceptualization of this phenomenon, it is noticeable that there are many points of view in the literature. First of all, several theories explain the essence of this concept. These are behavioural theory, transactional theory, obligatory theory, attitudinal theory, and a multidimensional approach (Mercurio, 2015). According to behavioural theory, the commitment of employees occurs as a consequence of their actions, i.e. behaviour. Some theorists use the term "volition" to explain this mechanism and state that if employees are free to make decisions about an activity in which they will participate, then they will feel a greater obligation and responsibility to carry out these activities to the end, as well as consider the costs of non-participation in these activities (Salancik, 1997). The essence of the transactional theory is that commitment to an organization results from the perceived loss of certain investments that an individual has made in a given organization. These investments are reflected in the invested time, effort and money. In short, commitment to an organization according to transactional theory is based on employee economic decisions. This theory derives its name from Becker's (1960) side-bet theory (Mercurio, 2015). The obligatory theory sees the basis for commitment to an organization in the employee's sense of obligation to that organization. This internalized sense of obligation can be based on the reciprocal benefits that the individual sees in the relationship with the organization (Mercurio, 2015). Attitudinal commitment theory sees an 
explanation for commitment in identifying the individual with the organization and feeling cohesive with it (Kanter, 1968 in Mercurio, 2015). Finally, there is a multidimensional approach to commitment adopted by several authors (Angle \& Perry, 1981; O'Reilly \& Chatman, 1986; Jaros, Jermier, Koehler, \& Sincich, 1993).

The most well-known multidimensional model of commitment is the one developed by Meyer and Allen (1991) according to which commitment is a three-dimensional concept. The mentioned authors believe that commitment is based on both behavioural theory and attitudinal theory. They also believe that these theories are not mutually exclusive. In support of this, they state that affective commitment can result from freely chosen behaviour of employees and over time grows into a true affective connection with the organization (Meyer \& Allen, 1991).

In the paper, the authors will implement the multidimensional approach to commitment advocated by the above-mentioned authors. Accordingly, the types of organizational commitment identified by them (affective, continuous and normative commitment) will be explained in more detail below (Meyer \& Allen, 1991)

When it comes to affective commitment, it is considered to be the most desirable manifestation of commitment, because it refers to the emotional connection and identification of employees with the organizations. Employees who have this type of commitment show a high degree of motivation, a strong belief in the goals of the organization, willingness to actively participate in its development etc. Meyer and Allen (1991) indicate that employees who develop this type of commitment stay in the organization because they want to.

As for continuous commitment, Meyer and Allen (1991) describe in the context of the costs associated with leaving an organization. In practice, this means that if employees estimate that the costs of leaving an organization will be high, they will be committed to that organization, not because they want to, but because they have to. The costs of leaving the organization include the costs of looking for a new job, but also the benefits that would be lost. Leaving the company can additionally cause intangible losses, such as broken social ties and contacts, loss of image resulting from work for a particular organization, etc. This type of commitment is often shown by employees who are at high positions on the hierarchical ladder because they usually put a lot of energy and effort to reach those positions. Continuous commitment is also shown by those employees who would have limited opportunities for alternative employment. According to some authors, this type of commitment could be increased if the organization had a clear plan for employee promotion, a good reward system and a career development plan (Akhtar \& Tan, 1994; Shouksmith, 1994).

Normative commitment, as the third type of commitment, reflects the feeling of obligation of employees to stay in the organization for certain reasons (scholarships, various types of help from the company, etc.). However, the factors that affect the normative commitment to the organization have a complex structure, because depending on the personality of the employee, they can have different effects. Seen from the perspective of the organization, this group of employees is important for the company because they can achieve high performance. However, over time, the level of normative commitment may weaken, which may have a negative impact on employees' performance.

\subsection{Employees' performance}

Employees' performance is commonly defined as the outcome of activities undertaken by employees that result from their efforts, abilities, and perceptions of the tasks delegated to them (Prasetya \& Kato, 2011). They reflect the degree of achievement in each job and the fulfilment of organizational regulations, expectations or requirements arising from the task assigned to them (Folorunso et al., 2014). Performance is often defined in the context of the quantity, quality and contribution that employees make to the achievement of organizational goals. They are also viewed as an overall outcome of work including efficiency and effectiveness (Hsu, 2005).

Because employees are the ones who make up organizations, the performances they achieve in their workplaces are also reflected in the performances on the organizational level (Zheng, Sharan, \& Wei, 2010). Starting from that fact, employers and managers need to know how they can get the best out of their employees. In this context, it is very useful to look at the results of research conducted in this area, because these results also suggest the directions in which the efforts of employers and managers to improve individual performance should go. Research in this area shows that the performances that employees achieve are influenced by a large number of 
factors, among which the most important are: leadership style, job satisfaction, salary satisfaction, the ability to participate in decisionmaking, etc.

\subsection{Hypothesis development}

Research on the relationship between organizational commitment and the performance that employees achieve was the subject of many studies. Furthermore, the relationship between the overall organizational commitment and performance, as well as the relationship between certain types of organizational commitment and performance were investigated.

There is a large body of research proving that overall organizational commitment and its types have a positive impact on employee performance (Negin, Omid, \& Ahmad, 2013; Chughtai \& Zafar, 2006; Khan, Ziauddin, \& Ramay, 2010). For example, Zefeiti and Mohamad (2017) examined the impact of employees' commitment on their productivity in public enterprises in Oman and proved that commitment has a positive and statistically significant impact on employees' productivity. Similarly, Zia ud and Kxan (2010) found that there is a positive relationship between overall organizational commitment and employees' performance and that all three types of organizational commitment have a positive and significant impact on employees' performance. A similar conclusion was reached by Folorunso and his associates (2014). They have proven that affective, normative, and continuous commitment together and independently exert a positive impact on employees' performance (Folorunso et al., 2014). Accordingly, our first hypothesis is:

\section{H1: Organizational commitment of employees} (overall and different types) has a positive impact on organizational performance.

Some authors have noted that the impact of certain types of organizational commitment does not have the same impact on organizational performance. Thus, for example, Khan et al. (2010) show that all types of organizational commitment have a positive and statistically significant impact on performance, but the contribution of the normative component of commitment to organizational performance is the greatest. Accordingly, our second hypothesis is:

\section{H2: Normative commitment of employees has} the greatest impact on organizational performance.
Some studies show that the relationship between all types of organizational commitment and performance can be both negative and positive, but statistically insignificant. For example, Clarke (2006) showed in his research that the relationship between continuous commitment and performance is negative, while overall commitment, as well as its affective and normative types, have a positive impact on company performance. Somers and Birnbaum (1998) found that commitment to an organization was positively correlated with employee performance and that relationship was statistically significant, whereas the relationship between continuous commitment and employee performance was not statistically significant. Accordingly, our next hypothesis is:

H3: The impact of continuous commitment of employees on organizational performance is not statistically significant.

When it comes to affective commitment, it is considered to be the most desirable manifestation of commitment, because employees who develop this type of commitment stay in the organization because they want to (Meyer \& Allen, 1991). Their job satisfaction is at a relatively high level, which encourages greater engagement and better performance. For these reasons, the impact of affective commitment on organizational performance is mostly positive and statistically significant, as evidenced by numerous studies (Kumari \& Afroz, 2013). Accordingly, our last hypothesis is:

H4: Affective commitment of employees has a positive and statistically significant impact on organizational performance.

\section{Research methodology}

To check the validity of the stated hypotheses, primary research was conducted. We examined which type of organizational commitment is present in employees in the organizations of the Republic of Serbia that were included in the research and whether there is a connection, both between certain types of organizational commitment and business performance and between overall organizational commitment and business performance. The research was conducted in the period from October 2017 to February 2018 by surveying employees in organizations in the Republic of Serbia. The questionnaire included 
two groups of questions. The first group consisted of general questions, related to gender, age and education of employees. The second group consisted of questions related to the types of organizational commitment. The questions were formulated according to a questionnaire created by Meyer and Allen (Meyer \& Allen, 1991). Employees were asked to answer questions related to types of organizational commitment from 1 to 5 on the Likert scale (where 1 means "I do not agree at all" and 5 "I completely agree"). Organizational performance in the paper is examined through the productivity of the employee, measured as income per employee. This indicator was chosen because data related to the achieved performance is usually business secret and employees did not enter it when filling out the questionnaire. Therefore, we used the official data from the Serbian Business Registers Agency SBRA website on the performances of the organizations, whose employees were interviewed. The income per employee, as an indicator of productivity, was chosen because some organizations whose employees were surveyed did not report a profit in the observation year.

The sample included 200 employees in 17 organizations operating in the territory of the Republic of Serbia. The organizations covered by the survey according to the Regulation on Classification of Activities (Službeni glasnik, 2010) belong to the sector of agriculture, forestry and fishing, manufacturing, water supply, sewerage and waste management and remediation activities, wholesale and retail trade, transportation and storage, financial and insurance activities, as well as human health and social work activities. As many as 13 companies belong to the group of large legal entities, while only 4 belong to the group of medium-sized legal entities.

Table 1 Sample structure

\begin{tabular}{|l|c|c|c|}
\hline \multirow{2}{*}{ Education } & \multicolumn{2}{|c|}{ Gender } & \multirow{2}{*}{ Total } \\
\cline { 2 - 3 } & Male & Female & \\
\hline Primary Education & $5.1 \%$ & $1.4 \%$ & $3.6 \%$ \\
\hline High school & $63.3 \%$ & $70.5 \%$ & $66.2 \%$ \\
\hline Higher education & $10.2 \%$ & $8.5 \%$ & $9.5 \%$ \\
\hline High education & $21.5 \%$ & $19.7 \%$ & $20.7 \%$ \\
\hline Total & $100.0 \%$ & $100.0 \%$ & $100.0 \%$ \\
\hline Age & & & \\
\hline$<25$ & $8.2 \%$ & $12.7 \%$ & $10.1 \%$ \\
\hline $26-40$ & $37.8 \%$ & $47.9 \%$ & $42.0 \%$ \\
\hline $41-55$ & $44.9 \%$ & $33.8 \%$ & $40.2 \%$ \\
\hline 56 and more & $9.2 \%$ & $5.6 \%$ & $7.7 \%$ \\
\hline Total & $100.0 \%$ & $100.0 \%$ & $100.0 \%$ \\
\hline & \multicolumn{3}{|c|}{ Source: The authors' calculations }
\end{tabular}

Out of the total number of distributed questionnaires, 31 were rejected due to incomplete answers, and 169 were retained. The structure of the sample, in terms of gender, education and age of respondents, is shown in Table 1. In the sample structure, women participated with $42.0 \%$, while there were slightly more men and they made up $58.0 \%$ of the respondents. Regarding the age structure, it was as follows: $10.1 \%$ were respondents under the age of $25,42.0 \%$ were respondents between 26 and 40, 40.2\% were respondents between 41 and $55,7.7 \%$ of respondents were older than 55 years. Also, 3.6\% have primary education, $66.2 \%$ of employees have a secondary school, $9.5 \%$ have higher education and $20.7 \%$ have high education.

\section{Research results}

The measurement scale used in the research consisted of three items. Examining its reliability, it is concluded that Cronbach's Alpha values of 0.828 indicate very good reliability and internal consistency of the scales in the sample. According to the data in Table 2, column Correlated ItemTotal Correlation, there is a high degree of correlation of each item with the overall results. As all values in the Cronbach's Alpha if Item Deleted column are less than the final alpha value $(0.828)$, we find that it is advisable to keep all items in the existing scale and that such a scale is comparable to research based on this scale. Also, the mean value of the correlation between items is 0.654 , and the correlation of pairs of items is from 0.593 to 0.687 , which indicates that the correlation between items is strong.

Table 2 Measurement scale reliability

\begin{tabular}{|l|c|c|}
\hline Item & $\begin{array}{c}\text { Corrected } \\
\text { Item-Total } \\
\text { Correlation }\end{array}$ & $\begin{array}{c}\text { Cronbach's } \\
\text { Alpha if Item } \\
\text { Deleted }\end{array}$ \\
\hline Affective commitment & .593 & .806 \\
\hline Continuous commitment & .687 & .697 \\
\hline Normative commitment & .682 & .699 \\
\hline Cronbach's Alpha & .828 & \\
\hline Sample size & 169 & \\
\hline \multicolumn{3}{|c|}{ Source: The authors' calculations } \\
\hline
\end{tabular}

To check the validity of the first hypothesis, a simple correlation and regression analysis were performed. The dependent variable in the model was labour productivity, measured as income per employee, while the independent variable was the level of overall commitment. The results of the correlation and regression analysis for testing the first hypothesis are shown in Table 3. 
Table 3 Correlation and regression analysis (employee commitment and performance of organizations in the Republic of Serbia)

\begin{tabular}{|l|c|c|}
\hline & Coefficients & Sig. \\
\hline (Constant) & $-1,413,998.068$ & .740 \\
\hline Organizational commitment & $3,301,993.883$ & .016 \\
\hline Pearson Correlation & .455 & .008 \\
\hline R Square & .034 & \\
\hline \multicolumn{2}{|c|}{ Source: The authors' calculations }
\end{tabular}

As it can be seen from Table 3, there is a moderate, direct and statistically significant relationship (0.455) between employees' commitment and the performance of organizations in the Republic of Serbia, as measured by labour productivity. In other words, with an increase in the degree of commitment, there is an increase in labour productivity and, conversely, a decrease in the level of commitment is accompanied by a decrease in labour productivity. Since this relationship is statistically significant, this conclusion can be generalized.

To examine the impact of employees' commitment on labour productivity more closely, a simple regression analysis was performed. The corresponding linear regression model that establishes the relationship between labour productivity as a dependent variable and organizational commitment (Table 3) has the following form:

Productivity $=-1,413,998.068+$

$3,301,993.883 \times$ organizational commitment

The value of the regression coefficient is 3,301,993.883 (Table 3). This means that an increase in the level of commitment among employees in the Republic of Serbia by 1, on a scale from 1 to 5 , leads to an increase in income per employee by $3,301,993.883$ dinars per year. This coefficient is statistically significant at the level of $5 \%$ so that the conclusion can be generalized. This proves the first hypothesis of the paper.

Before testing the impact of certain forms of commitment on labour productivity, correlation analysis was applied to examine the relationship between productivity and types of organizational commitment (affective, continuous and normative). A direct and statistically significant relationship was found between productivity, on the one hand, and affective commitment $(\mathrm{r}=.450$, $\mathrm{p}<.05$, medium-strong relationship), continuous commitment $(\mathrm{r}=.435, \mathrm{p}<.05$, medium-strong relationship) and normative commitment $(\mathrm{r}=.463$, $\mathrm{p}<.05$, medium-strong relationship), on the other hand.

Multiple regression was performed to check the impact of certain forms of commitment on labour productivity and to test hypotheses. The dependent variable in the model is labour productivity and the independent variables are an affective, continuous and normative commitment. The regression equation that represents the regression model is:

Productivity $=-1,738,179.627+$

$1,449,276.797 \times$ affective commitment +

$522,080.021 \times$ continuous commitment +

$1,480,939.639 \times$ normative commitment

The results are shown in Table 4.

Table 4 Influence of types of commitment on labour productivity in organizations in the Republic of Serbia

\begin{tabular}{|l|c|c|c|}
\hline & \multicolumn{2}{|c|}{ Beta } & \multirow{2}{*}{ Sig. } \\
\cline { 2 - 3 } & Unstandardized & Standardized & .392 \\
\hline (Constant) & $-1,738,179.627$ & & .045 \\
\hline $\begin{array}{l}\text { Affective } \\
\text { commitment }\end{array}$ & $1,449,276.797$ & .088 & .125 \\
\hline $\begin{array}{l}\text { Continuous } \\
\text { commitment }\end{array}$ & $522,080.021$ & .040 & .033 \\
\hline $\begin{array}{l}\text { Normative } \\
\text { commitment }\end{array}$ & $1,480,939.639$ & .103 & \\
\hline R & .488 & & \\
\hline R Square & .238 & & \\
\hline $\begin{array}{l}\text { Adjusted R } \\
\text { Square }\end{array}$ & .218 & \multicolumn{2}{|c|}{ Dependent Variable: Productivity } \\
\hline \multicolumn{4}{|c|}{ Source }
\end{tabular}

Source: The authors' calculations

As it can be seen from Table 4, the normative commitment has the greatest impact on labour productivity (St.B $=0.103$ ), and this coefficient is statistically significant. This proves the second hypothesis. Slightly weaker influence, concerning normative commitment, has affective commitment (St.B $=0.088)$, where the influence is statistically significant. This proves the fourth hypothesis. The weakest impact is recorded by continuous commitment $(\mathrm{St} . \mathrm{B}=0.040$ ), while this coefficient is not statistically significant. This proves the third hypothesis of the paper. The model explains $21.8 \%$ of the variability in labour productivity.

\section{Discussion and implications for human resources managers}

Our research, based on a sample of 169 employees in 17 organizations in Serbia, showed that organizational commitment, both overall and different types (normative, affective and 
continuous), has a great impact on employees' behaviour and thus the overall performance of the organization. The commitment of employees in organizations in Serbia explains almost $22 \%$ of the variability in the productivity of the organization.

When it comes to the different types of commitment, our research has shown that the impact of all types of commitment on the performance of organizations is not the same. The normative commitment had the greatest impact on the performance of organizations in Serbia, which is similar to the results obtained by Khan et al. (Khan et al., 2010). This can be explained by the fact that many employees in Serbia base their employment in organizations on recommendations, scholarships, professional practice and the like. As a consequence of this fact, employees often feel a moral obligation to justify such a privilege with great dedication and good results.

Our research has shown that the contribution of affective commitment to the performance of organizations in the Republic of Serbia is also positive and statistically significant, which is in line with the results of previous research (Kumari \& Afroz, 2013). However, the impact of affective commitment on productivity in organizations in the Republic of Serbia is smaller compared to the impact of normative commitment. This can be partly explained by the situation in the Republic of Serbia, which is characterized by organizations often behaving irresponsibly towards employees (often there are non-registration of workers, overtime longer than allowed by law, often unpaid, etc.) As a result, a relatively small number of employees in the Republic of Serbia develop affective commitment. Also, it is at such a level that there is no significant impact on performance. In addition, its impact is less than the impact of normative commitment.

Finally, our research showed that the impact of continuous commitment of employees to the performance of organizations in the Republic of Serbia is positive but statistically insignificant. These results are similar to the conclusions reached by Somers and Birnbaum (1998). This can be partly explained by the fact that an increasing number of employees in Serbia are thinking about leaving organizations and going abroad so that the "organizational co-dependency" that was present among the older generations is no longer present.

Having in mind the results of empirical research conducted on the territory of the Republic of Serbia, as well as what the relevant literature suggests regarding ways to increase employees' commitment, the measures for increasing it in domestic companies could be proposed. Some of the most important measures are as follow:

- Establishing communication channels Establishing adequate communication channels has always been considered as a good way to build employees' commitment. These channels must be two-way for information to move from employees to management and vice versa (Zangaro, 2001). In addition to the usual ways of communication (conversation, phone, e-mail, meetings, etc.), communication can be improved by introducing the so-called "open doors", "open books", etc.

- Involving employees in the decision-making process - Involving employees in the decisionmaking process is one of the best ways to increase the affective commitment of employees. The positive link between employees' involvement in the decision-making process and their commitment has also been confirmed in numerous empirical studies (Wainaina, Iravo \& Waititu, 2014; Zin \& Talet, 2016; Majeed, Ramaya, Mustamil, Nazri \& Jamshed, 2017; Paunescu, Popescu, \& Blid, 2018). However, in addition to the fact that the involvement of employees in the decision-making process has a positive impact on employees' commitment, it also has a positive impact on other phenomena related to employees, such as job satisfaction, empowerment, etc., which, on the other hand, are also closely related to the performance that employees achieve.

- Creating opportunities for inclusion in training programs - Employee retention in a particular organization often depends on their involvement in training programs. The reason why this is so can be explained by the fact that employees who are involved in training programs understand that organizations see them as valuable members of that organization and that is worth investing in them. In this way, the proposed measure contributes to the building of both affective and normative commitment. The positive link between employees' involvement in training programs is also confirmed by numerous empirical studies (Al-Emadi \& Marquardt, 2007; Aguinis \& Kraiger, 2009; Dias \& Silva, 2016; Foerster-Pastor \& Golowko, 2018). Given the importance of training of employees for the competitiveness of the organization, some authors in the training even see a central area of human resource management along with activities such as recruitment, selection and rewarding (Bulut \& Culha, 2010).

- Recruitment and selection of candidates 
whose values match the values of the organization - If candidates whose values match the values advocated by the organization are selected to fill job positions, such employees will likely be committed to that organization. Additionally, some authors suggest that it is very important for new employees (and useful for the organization) to feel like "insiders" very quickly, and in that sense recommend mentoring programs that can significantly contribute to this (Smith, 2000).

- Designing a reward system that recognizes individual achievements - A reward system is a very convenient mechanism for building employees' commitment and motivation if employees can see a direct link between their contribution and the rewards they receive. This is evidenced by many empirical studies (Nawab \& Bhatti, 2011; Rahaman, Mohani \& Rahman, 2016), so this mechanism should be used to build employees' commitment, but also other positive outcomes and phenomena related to them, such as job satisfaction, performance, organizational citizenship behaviour, etc. (Barber, Dunham \& Formisano, 1992; Chivu, Ciutacu \& Georgescu, 2015).

- An introduction of family-friendly practices - If organizations meet the needs of employees when it comes to their families (flexible working hours, part-time work, etc.), it is likely that this will positively affect the commitment of such employees. This is confirmed by empirical studies (Bae \& Yang, 2017) as well, so this mechanism, when it is possible, should be used for increasing the employees' commitment.

\section{Conclusion}

The paper dealt with the basic characteristics of the concept of organizational commitment, as well as the impact of this phenomenon on the performance that employees achieve. The paper points out that this is a frequently studied phenomenon, but at the same time, it is very important, which is evidenced in the great body of literature in this field. It is pointed out that organizational commitment is a multidimensional phenomenon that can be based on different bases, and in this regard, a distinction is made between the affective, continuous and normative commitment of employees.

In addition to reviewing and analysing the literature in the field of organizational commitment, the paper also presents the results of empirical research that focused on the relationship between employee commitment in organizations in the Republic of Serbia and the performance that these organizations achieve in terms of productivity. The results showed that the overall organizational commitment, as well as its types, have a positive impact on the productivity of organizations in the Republic of Serbia, with the impact of normative commitment on performance greater than other forms of commitment. At the same time, the contribution of continuous commitment to organizational performance, although positive is negligible (statistically insignificant). Following the obtained results, some recommendations for human resource managers in the Republic of Serbia were proposed with the aim of improvement of the business results through increased organizational commitment.

Key limitations of the paper are related to theoretical implications and sample size. The first limitation is based on the fact that empirical research was conducted in the Republic of Serbia, which is a small underdeveloped country. Therefore, the question that arises here is for how many people in the world the results of the study will be worth to consider? However, through a comparative analysis with similar researches from other countries, especially developed, it is possible to identify some similarities and differences. Consequently, some contribution to filling the gap in the Serbian literature in the field of human resource management can be made. The second limitation is related to a sample that included only 17 organizations from one region of the Republic of Serbia. On the other hand, having in mind the fact that in the Republic of Serbia it is relatively difficult to obtain empirical data and conduct primary research, which is why scientific papers are often theoretical (or empirical but based on the use of secondary data), any empirical research based on primary data in this country can provide useful information and intrigue other scientists to continue a deeper analysis in this field.sm

\section{References}

Aguinis, H., \& Kraiger, K. (2009). Benefits of training and development for individuals and teams, organizations, and society. Annual Review of Psychology, 60 (1), 451 474.

https://doi.org/10.1146/annurev.psych.60.110707.16350 $\underline{5}$

Akhtar, S., \& Tan, D. (1994). Reassessing and reconceptualizing the multidimensional nature of organizational commitment. Psychological Reports, 75 (3), 1379-1390.

https://doi.org/10.2466/pr0.1994.75.3.1379

Akintayo, D.I. (2010). Work-Family Role Conflict and Organizational Commitment Among Industrial Workers in Nigeria. Journal of Psychology and Counselling, 2 (1), 1-8. 
Al-Emadi, M. A. S. \& Marquardt, M. J. (2007). Relationship between employees' beliefs regarding training benefits and employees' organizational commitment in a petroleum company in the state of Qatar. International Journal of Training and Development, 11 (1), 49-70. https://doi.org/10.1111/j.1468-2419.2007.00269.x

Angle, H. L., \& Perry, J. L. (1981). An empirical assessment of organizational commitment and organizational effectiveness. Administrative Science Quarterly, 26 (1), $1-14$ https://doi.org/10.2307/2392596

Bae, K. B., \& Yang, G. (2017). The effects of family-friendly policies on job satisfaction and organizational commitment: A panel study conducted in South Korea. Public Personnel Management, 46 (1), 25-40. https://doi.org/10.1177/0091026016689669

Barber, A. E., Dunham, R. B., \& Formisano, R. A. (1992). The impact of flexible benefits on employee satisfaction: A field study. Personnel Psychology, 45 (1), 55-75. https://doi.org/10.1111/j.1744-6570.1992.tb00844.x

Becker, H. S. (1960). Notes on the concept of commitment. American Journal of Sociology, 66, 32-40. https://doi.org/10.1086/222820

Bulut, C., \& Culha, O. (2010). The effects of organizational training on organizational commitment. International Journal of Training and Development, 14 (4), 309-332. https://doi.org/10.1111/j.1468-2419.2010.00360.x

Chivu, L., Ciutacu, C., \& Georgescu, L. (2015). Household income in Romania. A challenge to economic and social cohesion. Procedia Economics and Finance, 22, 398401. https://doi.org/10.1016/S2212-5671(15)00310-X

Chughtai, A.A, \& Zafar, S. (2006). Antecedents and consequences of Organizational Commitment Among Pakistani University Teachers. Applied H.R.M Research, 11 (1), 39-64. http://dx.doi.org/10.4236/jhrss.2014.22009

Clarke. N (2006). The relationships between network commitment, its antecedents and network performance. Management Decision, 44 (9), 1183-1205. http://dx.doi.org/10.1108/00251740610707677

Dias, V. A., \& Silva, R. (2016). Organizational training and organizational commitment: a literature review and conceptual development. International Journal of Inovative Science, Engineering \& Technology, 3 (1), 387-399. https://doi.org/10.32535/ijabim.v3i1.86

Foerster-Pastor (Foerster-Metz), U. S., \& Golowko, N. (2018). The need for digital and soft skills in the Romanian business service industry. Management \& Marketing - Challenges for the Knowledge Society, 13 (1), 831-847. https://doi.org/10.2478/mmcks-2018-0008

Folorunso, O.O., Adewale, A.J., \& Abodunde, S.M. (2014). Exploring the effect of organizational commitment dimensions on employees performance: An empirical evidence from Academic Staff of Oyo State Owned Tertiary Institutions, Nigeria. International Journal of Academic Research in Business and Social Sciences, 4 (8), 275-286.

http://dx.doi.org/10.6007//JARBSS/v4-i8/1096

Hsu, P. Y. (2005). The research of the influence of crosscultural on the job performance: The case on Philippine \& Thailand labor in high-tech industry (Unpublished master's thesis, National Cheng Kung University, Taiwan). Retrieved from: http://etds.lib.ncku.edu.tw/etdservice/view metadata?et dun=U0026-0812200911253515
Irefin, P., \& Mechanic, M. (2014). Effect of commitment on organisational performance in Coca Cola Nigeria Limeited Maiduguri, Borno State. Journal of Humanities and Social Science, 19 (3), 33-41. https://doi.org/10.9790/0837-19313341

Jaros, S. J., Jermier, J. M., Koehler, J. W., \& Sincich, T. (1993). Effects of continuance, affective, and moral commitment on the withdrawal process: An evaluation of eight structural equation models. Academy of Management Journal, 36 (5), 951-995. https://psycnet.apa.org/doi/10.2307/256642

Kanter, R. M. (1968). Commitment and social organization: A study of commitment mechanisms in utopian communities. American Sociological Review, 33 (4), 499-517. https://psycnet.apa.org/doi/10.2307/2092438

Khan, M.R., Ziauddin, Jam, F.A., \& Ramay, M.I. (2010). The impacts of Organizational commitment on employee job performance. European Journal of Social Sciences, 15 (3), 292-298.

Kumari, N., \& Afroz, N. (2013). The Impact of Affective Commitment in Employees Life Satisfaction. The Impact of Affective Commitment in Employees Life Satisfaction, 13 (7), 1-7.

Majeed, N., Ramaya, T., Mustamil, N., Nazri, M. \& Jamshed, S. (2017). Transformational Leadership and Organizational Citizenship Behavior: Modeling Emotional Intelligence as Mediator. Management and Marketing. Challenges for the Knowledge Society, 12 (4), 571-590. https://dx.doi.org/10.1515/mmcks-2017$\underline{0034}$

Mercurio Z. A. (2015). Affective commitment as a core essence of organizational commitment: an integrative literature review. Human Resource Development Review, 14 (4), 389-414. https://doi.org/10.1177\%2F1534484315603612

Meyer, J. P \& Allen, N. J (1997). The measurement and antecedents of affective, continuance, and normative commitment to the organization. Journal of Occupational Psychology, 63 (1), 1-18. https://doi.org/10.1111/j.2044-8325.1990.tb00506.x

Meyer, J.P., \& Allen, N.J. (1991). A three-component conceptualization of organizational commitment. Human Resource Management Review, 1 (1), 61-89. https://doi.org/10.1016/1053-4822(91)90011-Z

Nawab, S. \& Bhatti, K. K. (2011). Influence of Employee Compensation on Organizational Commitment and Job Satisfaction: A Case Study of Educational Sector of Pakistan. International Journal of Business and Social Science, 2 (8), 25-32.

Negin, M., Omid, M., \& Ahmad, B.M. (2013). The Impact of Organizational Commitment on Employees job performance: A study of Meli Bank. International Journal of Contemporary Research in Business, 5 (5), 164-171.

O'Reilly, C. A., \& Chatman, J. (1986). Organizational commitment and psychological attachment: The effects of compliance, identification, and internalization on prosocial behavior. Journal of Applied Psychology, 71 (3), 492-499. https://psycnet.apa.org/doi/10.1037/0021$\underline{9010.71 .3 .492}$

Paunescu, C., Popescu, M. C. \& Blid, L. (2018). Business impact analysis for business continuity: Evidence from Romanian enterprises on critical functions. Management \& Marketing - Challenges for the Knowledge Society, 13 (3), 1035-1050. 
https://doi.org/10.2478/mmcks-2018-0021

Prasetya, A. \& Kato, M. (2011). The Effect of Financial and Non Financial Compensation to the Employee Performance. The 2nd International Research Symposium in Service Management. Yogyakarta, Indonesia.

Rahaman, S. M., A. Mohani \& Rahman, M. M. (2016). Organizational Commitment: Do Employees' Compensations and Benefits Matter? Journal of Business and Management, 18 (10), 135-141. https://doi.org/10.9790/487X-181005135141

Randall, D.M., Fedor, D.B., \& Longenecker, C.O. (1990). The behavioral expression of organizational commitment. Journal of Vocational Behavior, 36 (2), 210-224. https://psycnet.apa.org/doi/10.1016/00018791(90)90028-Z

Salancik, G. R. (1977). Commitment and the control of organizational behavior and belief. In B. M. Staw \& G. R. Salancik (Eds.). New directions in organizational behavior (pp. 1-54). Chicago: St. Clair-Press.

Shouksmith, G. (1994). Variables related to organizational commitment in health professionals. Psychological Reports, 74 (3), 707-711.

https://doi.org/10.2466\%2Fpr0.1994.74.3.707

Službeni glasnik RS br. 54/2010 (2010) Uredba o klasifikaciji delatnosti.

Smith, B. (2000). Managing generation X. USA Today Magazine, 129 (2666), 32-33.

Somers, M. J., \& Birnbaum, A. D. (1998). Work-related commitment and job performance: it's also the nature of the performance that counts. Journal of Organizational Behavior, 19 (6), 621-634.

https://psycnet.apa.org/doi/10.1002/(SICl)10991379(1998110)19:6\%3C621::AIDJOB853\%3E3.0.CO;2-B

Wainaina, L, Iravo, M. \& Waititu, A. (2014). Effect of

\section{$\triangle$ Correspondence}

\section{Biljana Đorđević}

University of Niš, Faculty of Economics

Trg kralja Aleksandra Ujedinitelja 11, 18105 Niš, Serbia

E-mail: biljana.djordjevic@eknfak.ni.ac.rs employee participation in decision making on the organizational commitment amongst academic staff in the private and public Universities in Kenya. International Journal of Advanced Research in Management and Social Sciences, 3 (12), 131-142.

Zangaro, G. (2001). Organizational commitment: A concept analysis. Nursing Forum, 36 (2), 14-22. https://doi.org/10.1111/j.1744-6198.2001.tb01179.x

Zefeiti, S., \& Mohamad, N. (2017). The Influence of Organizational Commitment on Omani Public Employees' Work Performance. International Review of Management and Marketing, 7 (2), 151-160.

Zheng, W., Sharan, K.,\& Wei, J. (2010). New Development of Organizational Commitment: A Critical Review (19602009). African Journal of Business Management, 4 (1), 12-20.

Zia ud, D., \& Khan, M.R. (2010). The Impact of Organizational Commitment on Employees Job Performance: A Study of Oil and Gas Sector of Pakistan. Rochester: Social Science Research Network.

https://dx.doi.org/10.2139/ssrn.1570544

Zin M. R. \& Talet, N. A. (2016). The effects of participation in decision making on organizational commitment: some empirical evidences. 3rd Business \& Management Conference, Lisbon. 